\title{
Retraction Note: Research on Desk Personalized Ventilation in Winter Ba- sed on CFD
}

\author{
Liu Fei ${ }^{*}$ and Zhang Dongliang \\ Guilin University of Aerospace Technology, Guilin 541004, P.R. China
}

\section{RETRACTION}

The Publisher and Editor have retracted this article [1] in accordance with good ethical practices. After a thorough investigations we believe that the peer review process was compromised. The article was published on-line on 26-06-2015.

\section{REFERENCE}

[1] L. Fei and Z. Dongliang, "Research on Desk Personalized Ventilation in Winter Based on CFD", The Open Mechanical Engineering Journal, vol. 9, pp. 411-415, 2015.

(C) Fei and Dongliang; Licensee Bentham Open.

This is an open access article licensed under the terms of the Creative Commons Attribution-Non-Commercial 4.0 International Public License (CCBY-NC 4.0) (https://creativecommons.org/licenses/by-nc/4.0/legalcode), which permits unrestricted, non-commercial use, distribution and reproduction in any medium, provided the work is properly cited.

*Address correspondence to this author at the Guilin University of Aerospace Technology, Guilin 541004, P.R. China; Tel: 15878350053;

E-mail:28455208@qq.com 